University of Nebraska - Lincoln

DigitalCommons@University of Nebraska - Lincoln

Faculty Papers and Publications in Animal

Science

Animal Science Department

2009

\title{
Effects of Sodium Chloride and Fat Supplementation on Finishing Steers Exposed to Hot and Cold Conditions
}

\author{
J. B. Gaughan \\ University of Queensland, j.gaughan@uq.edu.au \\ Terry L. Mader \\ University of Nebraska-Lincoln, tmader1@unl.edu
}

Follow this and additional works at: https://digitalcommons.unl.edu/animalscifacpub

Part of the Animal Sciences Commons

Gaughan, J. B. and Mader, Terry L., "Effects of Sodium Chloride and Fat Supplementation on Finishing Steers Exposed to Hot and Cold Conditions" (2009). Faculty Papers and Publications in Animal Science. 612.

https://digitalcommons.unl.edu/animalscifacpub/612

This Article is brought to you for free and open access by the Animal Science Department at DigitalCommons@University of Nebraska - Lincoln. It has been accepted for inclusion in Faculty Papers and Publications in Animal Science by an authorized administrator of DigitalCommons@University of Nebraska - Lincoln. 


\title{
Effects of sodium chloride and fat supplementation on finishing steers exposed to hot and cold conditions
}

\author{
J. B. Gaughan*1 and T. L. Mader $\dagger$ \\ *School of Animal Studies, The University of Queensland, Gatton, Australia, 4343; \\ and †Haskell Agricultural Laboratory, University of Nebraska-Lincoln, Concord 68728
}

\begin{abstract}
Three studies were conducted to evaluate the effects of supplemental fat and salt (sodium chloride) on DMI, daily water intake (DWI), body temperature, and respiration rate $(\mathrm{RR})$ in Bos taurus beef cattle. In Exp. 1 and 2, whole soybeans (SB) were used as the supplemental fat source. In Exp. 3, palm kernel meal and tallow were used. Experiment 1 (winter) and Exp. 2 (summer) were undertaken in an outside feedlot. Experiment 3 was conducted in a climate-controlled facility (mean ambient temperature $=29.9^{\circ} \mathrm{C}$ ). In Exp. 1, three diets, 1 ) control; 2) salt (control $+1 \%$ sodium chloride); and 3) salt-SB (control $+5 \% \mathrm{SB}+1 \%$ sodium chloride), were fed to 144 cattle $(\mathrm{BW}=327.7$ $\mathrm{kg}$ ), using a replicated $3 \times 3$ Latin square design. In Exp. 2, 168 steers $(\mathrm{BW}=334.1 \mathrm{~kg})$ were used. In Exp. 2 , the same dietary treatments were used as in Exp. 1 , and a $5 \%$ SB dietary treatment was included in an incomplete $3 \times 4$ Latin square design. In Exp. 3, three diets, 1) control; 2 ) salt (control $+0.92 \% \mathrm{NaCl})$; and 3 ) salt-fat (control $+3.2 \%$ added fat $+0.92 \% \mathrm{NaCl}$ ) were fed to 12 steers $(B W=602 \mathrm{~kg})$ in a replicated Latin square design. In Exp. 1, cattle fed the salt-SB diet had elevated $(P<0.05)$ tympanic temperature (TT; $\left.38.83^{\circ} \mathrm{C}\right)$ compared with cattle fed the control $\left(38.56^{\circ} \mathrm{C}\right)$ or salt $\left(38.50^{\circ} \mathrm{C}\right)$ diet. In Exp. 2, cattle fed the salt
\end{abstract}

and salt-SB diets had less $(P<0.05)$ DMI and greater $(P<0.05)$ DWI than cattle in the control and SB treatments. Cattle fed the salt-SB diet had the greatest $(P<0.05) \mathrm{TT}\left(38.89^{\circ} \mathrm{C}\right)$. Those fed only the salt diet or only the SB diet had the least $(P<0.05) \mathrm{TT}$, at 38.72 and $38.78^{\circ} \mathrm{C}$, respectively. Under hot conditions (Exp. 3), DMI of steers fed the salt and salt-fat diets declined by approximately $40 \%$ compared with only $24 \%$ for the control cattle. During hot conditions, DWI was greatest $(P<0.05)$ for steers on the salt-fat diet. These steers also had the greatest $(P<0.05)$ mean rectal temperature $\left(40.03 \pm 0.1^{\circ} \mathrm{C}\right)$ and $\mathrm{RR}(112.7 \pm$ 1.7 breaths/min). The RR of steers on the control diet was the least $(P<0.05 ; 98.3 \pm 1.7$ breaths $/ \mathrm{min})$. Although added salt plus fat decreased DMI under hot conditions, these data suggest that switching to diets containing the combination of added salt and fat can elevate body temperature, which would be a detriment in the summer but a benefit to the animal during winter. Nevertheless, adding salt plus fat to diets resulted in increased DWI under hot conditions. Diet ingredients or the combination of ingredients that can be used to regulate DMI may be useful to limit large increases in DMI during adverse weather events.

Key words: beef cattle, environmental stress, fat, salt

(C) 2009 American Society of Animal Science. All rights reserved.

J. Anim. Sci. 2009. 87:612-621

doi:10.2527/jas.2008-1125

\section{INTRODUCTION}

Hot environmental conditions can be a problem in feedlot cattle, causing large production losses, particularly for cattle consuming high-energy diets (Mader et al., 1999b; Gaughan et al., 2002; Mader, 2003). During periods of high heat load, reductions in DMI help bring metabolic heat production in balance with the capacity of the animal to dissipate heat. However, this has a

\footnotetext{
${ }^{1}$ Corresponding author: j.gaughan@uq.edu.au

Received April 23, 2008.

Accepted October 29, 2008.
}

negative effect on performance. In an effort to maintain energy intake with decreasing DMI, fat is often added to diets to increase energy density.

Dietary fats have a low heat increment in comparison with carbohydrates and proteins. The reduced heat increment of fat is due to a greater efficiency of utilization (Baldwin et al., 1980). High efficiency results in decreased heat production in the rumen when fats are used. However, inclusion of fat is limited in ruminants on the basis that diets with more than $8 \%$ total fat suppress ruminal starch digestion (Montgomery et al., 2008). The inclusion of dietary lipids in dairy cow diets has resulted in a reduction in heat load (Beede and Collier, 1986; Huber et al., 1994). However, others 
Table 1. Composition of diets fed in Exp. 1 (summer)

\begin{tabular}{|c|c|c|c|}
\hline \multirow[b]{2}{*}{ Item } & \multicolumn{3}{|c|}{ Treatment } \\
\hline & Control & Salt & Salt-soybean \\
\hline \multicolumn{4}{|l|}{ Ingredient, $\%$ of dietary DM } \\
\hline Alfalfa & 8.0 & 6.0 & 7.0 \\
\hline Dry-rolled corn & 86.0 & 87.0 & 81.0 \\
\hline Rumensin-Tylan supplement ${ }^{1}$ & 2.0 & 2.0 & 2.0 \\
\hline Liquid supplement $^{2}$ & 4.0 & 4.0 & 4.0 \\
\hline Salt & - & 1.0 & 1.0 \\
\hline Whole soybeans & - & - & 5.0 \\
\hline \multicolumn{4}{|l|}{ Nutrient composition $^{3}$} \\
\hline $\mathrm{NE}_{\mathrm{g}}, \mathrm{Mcal} / \mathrm{kg}$ & 1.43 & 1.43 & 1.43 \\
\hline $\mathrm{CP}, \%$ & 13.0 & 12.8 & 14.4 \\
\hline Fat, $\%$ & 3.8 & 3.8 & 4.5 \\
\hline Calcium, \% & 0.63 & 0.60 & 0.63 \\
\hline Potassium, \% & 0.68 & 0.65 & 0.74 \\
\hline Phosphorus, \% & 0.32 & 0.32 & 0.34 \\
\hline Chlorine, $\%$ & 0.20 & 0.80 & 0.81 \\
\hline Sodium, $\%$ & 0.10 & 0.50 & 0.50 \\
\hline Potassium:sodium & $6.8: 1$ & $1.3: 1$ & $1.5: 1$ \\
\hline $\mathrm{DCAD},{ }^{4} \mathrm{mEq} / 100 \mathrm{~g}$ & 58 & 35 & 43 \\
\hline
\end{tabular}

\footnotetext{
${ }^{1}$ Contained (on a DM basis): $35.11 \%$ ground corn; $30.62 \%$ soybean hulls; $19.96 \%$ wheat middlings; $4.21 \%$ molasses; $5.61 \%$ limestone; $3.10 \%$ soybean meal; 0.87\% Rumensin 80 (176.4 g of monensin/kg; Elanco Animal Health, Indianapolis, IN); and 0.52\% Tylan 40 (89 g of tylosin/kg; Elanco Animal Health).

${ }^{2}$ Contained (on a DM basis): $61.54 \% \mathrm{CP} ; 12.30 \%$ calcium; $5.39 \%$ salt; $3.85 \%$ potassium; $0.71 \%$ phosphorus; $0.43 \%$ magnesium; $0.148 \%$ zinc; $0.037 \%$ iron; $0.050 \%$ manganese; $0.021 \%$ copper; $0.002 \%$ iodine; $0.001 \%$ cobalt; $66,000 \mathrm{IU} / \mathrm{kg}$ of vitamin $\mathrm{A} ; 13,000 \mathrm{IU} / \mathrm{kg}$ of vitamin $\mathrm{D} ;$ and $44 \mathrm{IU} / \mathrm{kg}$ of vitamin $\mathrm{E}$.

${ }^{3} \mathrm{NRC}(1996)$.

${ }^{4}$ Dietary cation-anion difference $=(\mathrm{K}+\mathrm{Na}-\mathrm{Cl}), \mathrm{mEq} / 100 \mathrm{~g}$ of DM.
}

have shown little benefit (Knapp and Grummer, 1991; White et al., 1992; West, 1997).

Salt is a common feed ingredient, which can be used to regulate feed intake, particularly at amounts of $5 \%$ or more on a DM basis. However, when included at less than $1 \%$ on a DM basis, salt will tend to stimulate intake (La Manna et al., 1999). The amounts of salt that stimulate or restrict feed intake may vary, depending on feeding conditions and the amount of environmental stress to which cattle are exposed. The effects of switching cattle from low-salt, low-fat diets to diets containing elevated amounts of salt, fat, or both are unknown. In addition, the effects of supplemental salt and fat when fed to feedlot cattle exposed to cold stress or heat stress are largely unknown. The objectives of these studies were to evaluate the effects of introducing supplemental fat and salt into the diets of feedlot beef cattle exposed to either cold stress or heat stress.

\section{MATERIALS AND METHODS}

Experiments 1 and 2 were conducted at the University of Nebraska Haskell Agricultural Laboratory $\left(42^{\circ} 23^{\prime}\right.$ $\mathrm{N}$ and $96^{\circ} 57^{\prime} \mathrm{W}$ ) with the approval of the University of Nebraska-Lincoln Institutional Animal Care and Use Committee. Facility design and layout were reported by Mader et al. (1999a). Experiment 3 was conducted at The University of Queensland-Gatton Campus (27 $34^{\prime}$ $\mathrm{S}$ and $152^{\circ} 20^{\prime} \mathrm{E}$ ) with the approval of The University of Queensland Animal Ethics Committee. Facility design and layout were reported by Gaughan et al. (1999).
Exp. 1

Ninety-six crossbred heifers and 48 crossbred steers were used in this experiment. Before trial initiation, cattle were vaccinated (Bar-Vac 7/Somnus and Express 4; Boehringer Ingelheim Vetmedica Inc., St. Joseph, MO) and weighed. Body weight and sex (steers and heifers were not mixed) were used to allot animals randomly to 18 pens. At trial initiation, heifers and steers were implanted with Revalor-H or Revalor-S (Intervet Inc., Millsboro, DE), respectively, weighed (mean BW $=327.7 \mathrm{~kg}$ ), and sorted into the allotted pens. The steers were approximately $11 \mathrm{~kg}$ heavier than the heifers when the study commenced. A replicated $3 \times 3$ Latin square design was used, in which dietary treatments were compared during three 9 -d treatment periods. Between each treatment period, the control diet was fed to all cattle during a 5-d adjustment period. Diet treatments (Table 1) were 1) no supplemental salt or fat (CON1), 2) 1\% added sodium chloride (Salt1), and 3 ) $1 \%$ added sodium chloride + approximately $1 \%$ added fat by including $5 \%$ added whole soybeans (SSB1). All cattle were fed the CON1 diet before trial initiation. After cattle completed the third period, they remained on the last period treatment diet for $49 \mathrm{~d}$, until slaughter.

Dry matter intake and daily water intake (DWI) were recorded daily. Body weights were obtained after cattle completed the Latin square (d 43) and on the day before slaughter (d 92). Hot carcass weight, USDA yield grade, and marbling score were obtained at slaughter. 
Table 2. Composition of diets fed in Exp. 2 (winter)

\begin{tabular}{|c|c|c|c|c|}
\hline \multirow[b]{2}{*}{ Item } & \multicolumn{4}{|c|}{ Treatment } \\
\hline & Control & Salt & Soybean & Salt-soybean \\
\hline \multicolumn{5}{|l|}{ Ingredient, $\%$ of dietary DM } \\
\hline Alfalfa & 6.0 & 4.0 & 4.0 & 3.8 \\
\hline Corn silage & 4.0 & 4.0 & 8.0 & 8.0 \\
\hline Dry-rolled corn & 82.7 & 83.7 & 78.0 & 78.0 \\
\hline Rumensin-Tylan supplement $^{1}$ & 2.0 & 2.0 & 2.0 & 2.0 \\
\hline Liquid supplement ${ }^{2}$ & 3.3 & 3.3 & 3.0 & 3.0 \\
\hline Soybean meal & 2.0 & 2.0 & - & - \\
\hline Salt & - & 1.0 & - & 1.0 \\
\hline Whole soybeans & - & - & 5.0 & 5.0 \\
\hline \multicolumn{5}{|l|}{ Nutrient composition $^{3}$} \\
\hline $\mathrm{NE}_{\mathrm{g}}, \mathrm{Mcal} / \mathrm{kg}$ & 1.43 & 1.43 & 1.45 & 1.45 \\
\hline $\mathrm{CP}, \%$ & 13.3 & 13.0 & 13.5 & 13.4 \\
\hline Fat, $\%$ & 3.81 & 3.79 & 4.61 & 4.59 \\
\hline Calcium, \% & 0.53 & 0.51 & 0.49 & 0.48 \\
\hline Potassium, \% & 0.71 & 0.68 & 0.75 & 0.73 \\
\hline Phosphorus, \% & 0.33 & 0.33 & 0.34 & 0.33 \\
\hline Chlorine, $\%$ & 0.18 & 0.78 & 0.17 & 0.77 \\
\hline Sodium, \% & 0.09 & 0.48 & 0.08 & 0.47 \\
\hline Potassium:sodium & $7.9: 1$ & $1.4: 1$ & $9.4: 1$ & $1.6: 1$ \\
\hline $\mathrm{DCAD},{ }^{4} \mathrm{mEq} / 100 \mathrm{~g}$ & 62 & 38 & 66 & 43 \\
\hline
\end{tabular}

${ }^{1}$ Contained (on a DM basis): $35.11 \%$ ground corn: $30.62 \%$ soybean hulls; $19.96 \%$ wheat middlings: $4.21 \%$ molasses; $5.61 \%$ limestone; $3.10 \%$ soybean meal; $0.87 \%$ Rumensin 80 (176.4 g of monensin/kg; Elanco Animal Health, Indianapolis, IN); and 0.52\% Tylan 40 (89 g of tylosin $/ \mathrm{kg}$; Elanco Animal Health).

${ }^{2}$ Contained (on a DM basis): $61.54 \%$ CP; $12.30 \%$ calcium; $5.39 \%$ salt; $3.85 \%$ potassium; $0.71 \%$ phosphorus; $0.43 \%$ magnesium; $0.148 \%$ zinc; $0.037 \%$ iron; $0.050 \%$ manganese; $0.021 \%$ copper; $0.002 \%$ iodine; $0.001 \%$ cobalt; $66,000 \mathrm{IU} / \mathrm{kg}$ of vitamin $\mathrm{A} ; 13,000 \mathrm{IU} / \mathrm{kg}$ of vitamin $\mathrm{D}$; and $44 \mathrm{IU} / \mathrm{kg}$ of vitamin $\mathrm{E}$.

${ }^{3} \mathrm{NRC}(1996)$.

${ }^{4}$ Dietary cation-anion difference $=(\mathrm{K}+\mathrm{Na}-\mathrm{Cl}), \mathrm{mEq} / 100 \mathrm{~g}$ of DM.

During the last $6 \mathrm{~d}$ of the second period, tympanic temperatures (TT) of heifers only were recorded by using Stowaway XTI data loggers and thermistors (Onset Corporation, Pocasset, MA). The thermistor was inserted approximately 100 to $125 \mathrm{~mm}$ into the ear canal until the tip was near the tympanic membrane. The loggers recorded temperatures at 1-h intervals in 24 animals from 6 pens ( 8 animals/treatment). Treatments for the second period were imposed approximately $30 \mathrm{~d}$ after the beginning of the summer season.

\section{Exp. 2}

In a winter study, 168 crossbred steers were vaccinated (Vision 7/Somnus and Titanium 5 PHM Bac 1; Intervet Inc.), dewormed (Safe-Guard; Intervet Inc.), treated for external parasites (Saber; Schering Plough Animal Health, Union, NJ), and weighed before trial initiation. This BW was used to allot animals randomly to 24 pens. At trial initiation, cattle were implanted (Revalor-S; Intervet Inc.), weighed (mean BW = 334.1 $\mathrm{kg}$ ), and sorted to their allotted pens. A $3 \times 4$ incomplete Latin square design was used, with three 10-d treatment periods. Between each treatment period, an 11-d adjustment period was used, in which the CON diet was fed to all cattle. Diet treatments (Table 2) were 1) no added supplemental fat or salt (CON2), 2) $1 \%$ added sodium chloride (Salt2), 3) 5\% added soybeans (SB), and 4) $1 \%$ added sodium chloride $+5 \%$ added soybeans (SSB2). The CON2 diet was fed to all cattle $9 \mathrm{~d}$ before initiating the first treatment period. After cattle completed the third period of the Latin square, they remained on their respective diets for an additional $38 \mathrm{~d}$, and were then slaughtered. When the $10 \mathrm{~d}$ from the final period of the Latin square was included, the cattle were on the final diets for $48 \mathrm{~d}$.

Feed intake and DWI were recorded daily. Body weights were obtained on the day before slaughter. Tympanic temperatures were recorded at 1 -h intervals in 3 animals from 2 pens ( 6 animals/treatment) of each treatment for the last $8 \mathrm{~d}$ of periods 1 and 2 . Treatment periods were imposed in early winter, $30 \mathrm{~d}$ after the winter season began, and in midwinter. The TT data were obtained from the same animals in each period, using the procedures described in Exp. 1.

\section{Exp. 3}

Before the study commenced, 12 Angus steers were weighed, ear tagged, vaccinated against clostridial disease (Coopers Tasax 5 in 1, Mallinckrodt Veterinary, North Ryde, New South Wales, Australia), treated for internal and external parasites (Cydectin; Cynamid Websters P/L, Castle Hill, New South Wales, Australia), and vaccinated against tick fever with a trivalent vaccine (Tick Fever Research Centre, Wacol, Queensland, Australia). No implants were used. Three dietary treatments (Table 3) were used: 1) no added salt or fat 
Table 3. Ingredient and chemical composition of diets fed to steers in Exp. 3

\begin{tabular}{|c|c|c|c|}
\hline \multirow[b]{2}{*}{ Item } & \multicolumn{3}{|c|}{ Diet } \\
\hline & Control & Salt & Salt-fat \\
\hline \multicolumn{4}{|l|}{ Ingredient, $\%$ of $\mathrm{DM}$} \\
\hline Barley, rolled & 15.00 & 15.00 & 15.00 \\
\hline Sorghum, rolled & 20.00 & 20.00 & 20.00 \\
\hline Wheat, rolled & 38.70 & 37.50 & 32.50 \\
\hline Soybean meal, $47 \% \mathrm{CP}$ & 5.00 & 5.00 & 5.00 \\
\hline Palm kernel meal & 8.69 & 8.92 & 12.00 \\
\hline Tallow & - & - & 1.95 \\
\hline Molasses & 7.00 & 7.00 & 7.00 \\
\hline Dicalcium phosphate & 0.348 & 0.378 & 0.358 \\
\hline Limestone & 1.96 & 1.95 & 1.96 \\
\hline Salt & 0 & 0.923 & 0.915 \\
\hline Sodium bentonite & 2.00 & 2.00 & 2.00 \\
\hline Sodium bicarbonate & 0.50 & 0.50 & 0.50 \\
\hline Urea & 0.777 & 0.804 & 0.792 \\
\hline Rumensin premix ${ }^{1}$ & 0.025 & 0.025 & 0.025 \\
\hline \multicolumn{4}{|c|}{ Nutrient composition, DM basis } \\
\hline $\mathrm{NE}_{\mathrm{g}}, \mathrm{Mcal} / \mathrm{kg}$ & 1.19 & 1.17 & 1.24 \\
\hline $\mathrm{CP}, \%$ & 13.0 & 13.0 & 13.0 \\
\hline Fat, $\%$ & 2.9 & 2.9 & 5.1 \\
\hline Calcium, \% & 0.86 & 0.87 & 0.87 \\
\hline Potassium, $\%$ & 0.78 & 0.78 & 0.78 \\
\hline Phosphorus, \% & 0.39 & 0.39 & 0.39 \\
\hline Chlorine, $\%$ & 0.29 & 0.85 & 0.84 \\
\hline Sodium, $\%$ & 0.19 & 0.56 & 0.56 \\
\hline Potassium:sodium & $4.1: 1$ & $1.4: 1$ & $1.4: 1$ \\
\hline $\mathrm{DCAD},{ }^{2} \mathrm{meq} / 100 \mathrm{~g}$ & 68 & 49 & 50 \\
\hline
\end{tabular}

(CON3), 2) $1 \%$ added salt (Salt3), and 3) $1 \%$ added salt $+3 \%$ added fat (Salt+fat) from palm kernel meal and tallow. Cattle were stepped up to a grain-based finisher diet (CON3; Table 3) over a 21-d period. The steers had ad libitum access to this diet for $90 \mathrm{~d}$ before being weighed (mean $\mathrm{BW}=602.0 \mathrm{~kg}$ ) and assigned to a replicated $3 \times 3$ factorial arrangement of treatments, which were imposed under environmentally controlled conditions.

Steers were initially adapted to diets in 6 individual outside holding pens $(3 \times 5 \mathrm{~m})$. Each pen had an individual waterer and feeder and a shaded area of 3 $\times 1.5 \mathrm{~m}$. Six steers (group 1) were randomly selected and allocated to these pens $7 \mathrm{~d}$ before entering the climate facilities. During this 7 -d period, 2 steers remained on the CON3 diet, and the other 4 steers were switched from the CON3 to the Salt3 (2 steers) or the Salt + fat $(2$ steers) diet. Steers were then moved to a climate-controlled facility for $7 \mathrm{~d}$ ( $2 \mathrm{~d}$ of thermoneutral conditions $+5 \mathrm{~d}$ of hot conditions). On $\mathrm{d} 8$, the cattle returned to their individual pens, where the remaining 6 steers (group 2) had been fed the CON3, Salt3, or Salt+fat diets (2 steers/diet) in a manner similar to group 1. At this same time, steers in group 2 were moved to the climate-controlled facilities. During the second and third periods of this study, steers were managed similarly to those described for the first period, except that pairs of steers within a group were not fed the same diet, as in previous periods. Feed offered and refusals were recorded daily when cattle were housed in individual pens at the feedlot and while in the climate facility.

Initially, each steer was randomly assigned to 1 of 6 $(3 \times 1 \mathrm{~m})$ stalls in the climate facility. In subsequent periods, steers were randomly assigned to a stall in which they had not previously been housed. Each stall was fitted with an individual water bowl and feed bin. The steers were tied to the front of the stall by a $1-\mathrm{m}-$ long lead attached to a head halter. This allowed the steers to stand and lie down, move forward and backward within the pen, and undertake normal grooming behavior.

During the first $2 \mathrm{~d}$ (adaptation phase) in the climate facility, the steers were exposed to thermoneutral conditions, with temperatures set to range from 19 to $23^{\circ} \mathrm{C}$. After the thermoneutral period, the cattle were exposed to a cyclic temperature regimen of 25 to $36^{\circ} \mathrm{C}$ for a 5 -d period. The facility was heated from 0800 to $1500 \mathrm{~h}$. After $1500 \mathrm{~h}$, the facility was allowed to gradually decrease in temperature to depict normal cyclic summer temperatures. The steers were monitored for $12 \mathrm{~h}$ each day, with observations being taken on the second thermoneutral day and on each of the $5 \mathrm{~d}$ of hot conditions.

While cattle were in the climate-controlled facility, individual rectal temperatures were measured at 5-min intervals (Gaughan et al., 1999). Individual respiration rate was measured by visual observation of flank 
movement. The time taken for 10 breaths was recorded hourly from 0600 to $1800 \mathrm{~h}$.

Dry bulb and wet bulb temperatures were measured at 5-min intervals by using type $\mathrm{T}$ thermocouples positioned at a midpoint in the facility $(1 \mathrm{~m}$ above the floor). The thermocouples were attached to a data logger (model DT50, Data Electronics Australia P/L, Rowville Victoria), which converted the voltage input to a temperature reading. Air pressure was recorded hourly by using a pressure transducer (PDS-Baro Barometric Pressure Transducer, Pacific Data Systems, Brisbane, Australia). Air movement over the cattle ranged from 1.2 to $2.2 \mathrm{~m} / \mathrm{s}$. A 12-h photoperiod was used. Relative humidity was calculated by using the equation of Raymond (2000). The temperature-humidity index (THI; adapted from Thom 1959), THI $=\{(0.8$ $\times$ ambient temperature $)+$ relative humidity $\times$ (ambient temperature -14.3$)]+46.4\}$, was determined by using ambient temperature and the calculated relative humidity (in decimal form).

\section{Statistical Analysis}

Data from Exp. 1 were analyzed by using PROC MIXED (SAS Inst. Inc., Cary, NC). Performance and carcass data were analyzed as a completely random design with final diet and pen in the model. Dry matter intake and DWI were analyzed by using repeated measures in a $3 \times 3$ Latin square design. The model included the effects of diet, period, day of the period, and the interaction of day $\times$ diet as fixed effects, with pen as a random effect. The specified term for the repeated statement was day within period. Tympanic temperatures were analyzed by using a repeated measures model that included diet, time of day, day, and the interaction of diet $\times$ time of day as fixed effects, with animal included as a random effect. The specified term for the repeated statement was time of day.

Data from Exp. 2 were analyzed by using PROC MIXED. Carcass data were analyzed as a completely random design with final diet in the model. Dry matter intake and DWI were analyzed by using repeated measures for an incomplete $3 \times 4$ Latin square design. The model included the effects of diet, day of period, period, and the interaction of day $\times$ diet as fixed effects, with pen as a random effect. The specified term for the repeated statement was day within period. Tympanic temperatures were analyzed by using a repeated measures model that included diet, time of day, day, period, and the interaction of diet $\times$ time of day as fixed effects, with animal included as a random effect. The specified term for the repeated statement was time of day within period.

In Exp. 3, data were analyzed by using PROC GLM and PROC REG of SAS. The statistical models included period, group, steer within group, climate, diet, climate $\times$ diet, day, and 2- and 3-way interactions of climate and diet with day. Means for the measured variables, rectal temperature, respiration rate, and DMI were separated by using an LSD test when climate $\times$ diet interactions occurred $(P<0.05)$. Rectal temperature and respiration rate were analyzed by using repeated measures ANOVA. The specified term for the repeated statement was steer within day. When significance $(P$ $<0.05)$ was indicated, the means were separated by using Tukey's Studentized range test.

\section{RESULTS}

\section{Climatic Conditions}

Mean ambient temperatures for Exp. 1 and 2, during the periods when TT were obtained, were above the 10 -yr normal in both the summer $\left(26.1\right.$ vs. $\left.22.3^{\circ} \mathrm{C}\right)$ and winter $\left(-2.9\right.$ vs. $-4.9^{\circ} \mathrm{C}$; Table 4$)$. Based on THI values (mean $=74.4$ in summer and 31.3 in winter), the conditions were sufficient to produce moderate stress in both seasons. Generally, a THI outside the range of 35 to 74 is considered sufficient to elicit stress responses in beef cattle (De Dios and Hahn, 1993). During the thermoneutral period of Exp. 3, the dry bulb temperature ranged from 19.3 to $23.9^{\circ} \mathrm{C}$, with a mean of $21.6 \pm$ $0.1^{\circ} \mathrm{C}$. Mean relative humidity was $72.2 \pm 0.2 \%$ (range 70.9 to $82.4 \%$ ). Mean wet bulb temperature during thermoneutral period was $17.5 \pm 0.1^{\circ} \mathrm{C}$ (range 16 to $19^{\circ} \mathrm{C}$ ). Mean THI during the thermoneutral period was 68.1 units. Under hot conditions, mean dry bulb temperature was $29.9 \pm 0.1^{\circ} \mathrm{C}$ (range 25.8 to $33.5^{\circ} \mathrm{C}$ ). Mean relative humidity was $76.8 \pm 0.2 \%$. Wet bulb temperature ranged from 21.0 to $33.3^{\circ} \mathrm{C}$, with a mean of $24.8 \pm$ $0.1^{\circ} \mathrm{C}$. Mean THI was 83.0 units.

\section{$D M I$ and $D W I$}

In Exp. 1 (summer), the addition of salt or soybeans (Salt1 and SSB1 treatments) did not affect $(P>0.05)$ DMI or DWI (Table 5). In Exp. 2 (winter), the addition of salt (Salt2 and SSB2 treatments) decreased DMI ( $P$ $<0.10)$, increased DWI $(P<0.05)$, and decreased the DMI-to-DWI ratio $(P<0.05)$. Winter DMI averaged $1.6 \mathrm{~kg} / \mathrm{d}$ more than summer intakes. This difference would indicate that the winter cattle consumed nearly $17 \mathrm{~g} / \mathrm{d}$ more salt than the summer cattle. There tended to be a diet $\times$ day of period interaction $(P<0.10)$ for DMI in Exp. 2. The DMI of the CON2 and SB treatment groups remained fairly constant throughout the period, whereas DMI for the Salt2 treatment group declined over the first $4 \mathrm{~d}$ and then increased to the CON2 DMI amount (data not shown). Feeding supplemental salt and fat in the form of soybeans (SSB2 treatment) decreased DMI immediately, but by d 5 , DMI were statistically similar among treatment groups (data not shown).

Diet $\times$ day of period interactions $(P<0.01)$ for DWI were also found in Exp. 2. On d 1 of the period, DWI was greater for all cattle fed the Salt2 and SSB2 diets when compared with cattle fed the CON2 diet. However, DWI declined for all cattle on d 2 and 3, rebounded 
Table 4. Ambient temperature $\left(\mathrm{T}_{\mathrm{a}}\right)$, mean relative humidity $(\mathrm{RH})$, mean temperature-humidity index (THI), and mean wind speed (WS) for Exp. 1, 2, and 3 during the periods when tympanic (Exp. 1 and 2) and rectal temperatures (Exp. 3) were obtained

\begin{tabular}{lccccc}
\hline \hline Item & Mean $\mathrm{T}_{\mathrm{a}},{ }^{\circ} \mathrm{C}$ & Maximum $\mathrm{T}_{\mathrm{a}},{ }^{\circ} \mathrm{C}$ & Minimum $_{\mathrm{a}},{ }^{\circ} \mathrm{C}$ & $\mathrm{RH}, \%$ & $\mathrm{THI}^{1}$ \\
\hline Exp. 1 & 26.1 & 34.1 & 20.7 & 69.7 & 74.4 \\
Exp. 2 & -2.9 & 3.1 & -8.5 & 64.7 & 31.3 \\
Exp. 3 $^{2}$ & 21.6 & 23.9 & 19.3 & 72.2 & 68.1 \\
Exp. 3 $^{3}$ & 29.9 & 33.5 & 25.8 & 76.8 & 83.0 \\
\hline
\end{tabular}

${ }^{1} \mathrm{THI}=\{0.8 \times$ ambient temperature $+[($ relative humidity $\times($ ambient temperature -14.4$)]+46.4\}$.

${ }^{2}$ Thermoneutral period.

${ }^{3}$ Hot period.

for cattle fed the Salt2 and SSB2 diets, and then stabilized and became similar among all treatment groups by d 5 and remained similar for the duration of the period (data not shown).

During Exp. 3, DMI was less for each treatment during the hot period compared with the intakes under thermoneutral conditions (Table 6). Similar reductions in DMI between the thermoneutral and the hot period occurred in steers on the Salt3 (38.3\%) and Salt+fat $(39.4 \%)$ diets. In contrast, a $24 \%$ reduction in DMI was experienced by the CON3 group. Dry matter intake during the thermoneutral period was not influenced by dietary treatment, although trends in DMI differed $(P$ $>0.05$ ) among treatments between the thermoneutral and hot periods. A diet treatment $\times$ climate period interaction was found for DMI $(P<0.05)$. The steers fed the CON3 diet had reduced DMI compared with steers fed the Salt3 and Salt+fat diets under thermoneutral conditions, whereas steers fed the Salt3 and Salt+fat diets had reduced DMI under hot conditions. Under thermoneutral conditions, steers on the Salt+fat diet had numerically $14.8 \%$ greater energy intake than those on the CON3 diet. Under hot conditions, steers in the CON3 group had approximately $10 \%$ greater DMI than steers in the Salt3 and Salt+fat groups.

Daily water intakes were similar among diets under thermoneutral conditions and increased by $20 \mathrm{~L} / \mathrm{d}$ when cattle were exposed to hot conditions. Under hot conditions, steers in the Salt+fat group used more $(P<$ $0.05)$ water than those in the CON3 and Salt3 groups. In addition, under hot conditions, the DWI-to-DMI ratio tended to be greatest for steers in the Salt+fat group. During the hot period, the ratio increased for all treatments.

\section{Physiological Responses}

In Exp. 1, the cattle fed the SSB1 diet had a greater $(P<0.10) \mathrm{TT}\left(38.83^{\circ} \mathrm{C}\right)$ when compared with cattle fed the CON1 $\left(38.56^{\circ} \mathrm{C}\right)$ and Salt diets $\left(38.50^{\circ} \mathrm{C}\right.$; Table 5 ), but there were no differences in TT between steers fed the CON1 and Salt1 diets. There were differences $(P<0.05)$ in TT among all diets in Exp. 2. Similar to Exp. 1, the cattle fed the SSB2 diet had the greatest TT $\left(38.89^{\circ} \mathrm{C}\right)$. The TT of cattle in the CON2 group was $38.83^{\circ} \mathrm{C}$, followed by $\mathrm{TT}$ of 38.78 and $38.72^{\circ} \mathrm{C}$, respectively, for cattle on the SB and Salt2 diets. The addition of salt and soybeans resulted in an increase in TT in the winter $(P<0.05)$ and summer $(P<0.10)$, whereas providing either added salt or soybeans in the diet decreased $(P<0.05)$ TT when compared with cattle in the CON2 group in the summer.

Over the $5 \mathrm{~d}$ of hot conditions in Exp. 3, steers on the Salt + fat diet had the greatest $(P<0.05)$ mean rectal temperature (Table 6 ). The mean rectal temperature was similar for the other treatments. The rectal tem-

Table 5. Dry matter intake, daily water intake (DWI), and tympanic temperature (TT) for cattle in Exp. 1 (summer) and Exp. 2 (winter)

\begin{tabular}{lrrrrr}
\hline \hline & \multicolumn{3}{c}{ Treatment } \\
\cline { 2 - 4 } Item & Control & Salt & Soybean & Salt-soybean & SEM \\
\hline Exp. 1 & & & & \\
DMI, kg/d & 9.72 & 9.66 & - & 9.60 & 0.09 \\
DWI, L/d & 31.81 & 32.85 & - & 31.81 & 0.60 \\
DWI:DMI, L/kg & 3.28 & 3.40 & - & 3.32 & 0.13 \\
TT, ${ }^{\circ} \mathrm{C}$ & $38.56^{\mathrm{a}}$ & $38.50^{\mathrm{a}}$ & - & $38.83^{\mathrm{b}}$ & 0.14 \\
Exp. 2 & & & & & \\
DMI, kg/d & $11.53^{\mathrm{b}}$ & $11.27^{\mathrm{a}}$ & $11.51^{\mathrm{b}}$ & $11.15^{\mathrm{a}}$ & 0.17 \\
DWI, L/d & $16.84^{\mathrm{d}}$ & $19.11^{\mathrm{c}}$ & $17.22^{\mathrm{d}}$ & $18.83^{\mathrm{c}}$ & 0.49 \\
DWI:DMI, L/kg & $1.46^{\mathrm{d}}$ & $1.70^{\mathrm{c}}$ & $1.49^{\mathrm{d}}$ & $1.76^{\mathrm{c}}$ & 0.04 \\
TT, ${ }^{\circ}{ }^{\circ} \mathrm{C}$ & $38.83^{\mathrm{e}}$ & $38.72^{\mathrm{c}}$ & $38.78^{\mathrm{d}}$ & $38.89^{\mathrm{f}}$ & 0.01 \\
\hline
\end{tabular}

${ }^{\mathrm{a}, \mathrm{b}}$ Means within a row with unlike superscripts differ $(P<0.10)$.

${ }^{\mathrm{c}-\mathrm{f}}$ Means within a row with unlike superscripts differ $(P<0.05)$.

${ }^{1}$ Salt $\times$ soybean interaction $(P<0.001)$. 
Table 6. Dry matter intake, daily water intake (DWI), rectal temperature (RT), and respiration rate (RR) under thermoneutral and hot conditions during Exp. 3

\begin{tabular}{lcccc}
\hline \hline & \multicolumn{3}{c}{ Diet } \\
\cline { 2 - 3 } & Control & Salt & Salt-fat & SEM \\
\cline { 2 - 3 } Item & & & & \\
\hline Thermoneutral & 5.33 & 5.80 & 6.12 & 0.68 \\
DMI, ${ }^{1} \mathrm{~kg} / \mathrm{d}$ & 18.2 & 20.1 & 22.8 & 1.2 \\
DWI, L/d & 3.41 & 3.47 & 3.73 & 0.6 \\
DWI:DMI, L/kg & 38.79 & 38.63 & 38.71 & 0.11 \\
RT, ${ }^{\circ} \mathrm{C}$ & $53.7^{\mathrm{a}}$ & $53.8^{\mathrm{a}}$ & $60.1^{\mathrm{b}}$ & 3.4 \\
RR, breaths/min & & & & \\
Hot & 4.04 & 3.58 & 3.71 & 0.89 \\
DMI, ${ }^{1} \mathrm{~kg} / \mathrm{d}$ & $39.0^{\mathrm{a}}$ & $40.6^{\mathrm{a}}$ & $46.1^{\mathrm{b}}$ & 1.8 \\
DWI, L/d & 9.64 & 11.32 & 12.43 & 0.92 \\
DWI:DMI, L/kg & $39.54^{\mathrm{a}}$ & $39.52^{\mathrm{a}}$ & $40.03^{\mathrm{b}}$ & 0.09 \\
RT, ${ }^{\circ} \mathrm{C}$ & $98.3^{\mathrm{a}}$ & $110.2^{\mathrm{b}}$ & $112.7^{\mathrm{b}}$ & 1.7 \\
RR, breaths/min & & & \\
\hline
\end{tabular}

${ }^{\mathrm{a}, \mathrm{b}}$ Means within a row with unlike superscripts differ $(P<0.05)$.

${ }^{1}$ Diet $\times$ climate period interaction $(P<0.05)$.

perature of steers on the Salt+fat diet was greater $(P$ $<0.001)$ than the rectal temperatures of steers in the other treatments for the last $4 \mathrm{~d}$ of the hot period. Rectal temperature increased over the first $4 \mathrm{~d}$ of hot conditions and then remained fairly stable. There were no treatment differences in rectal temperature under thermoneutral conditions.

Respiration rates were not assessed in Exp. 1 or 2. Under hot conditions, steers fed the Salt3 and Salt+fat diets in Exp. 3 had greater $(P<0.05)$ mean respiration rates than steers fed the CON3 diet (Table 6). Maximum respiration rate occurred for all treatments on $\mathrm{d} 4$ of the hot period. Daily respiration rates for steers fed the Salt3 and CON3 diets were similar $(P>0.05)$ during the thermoneutral period and were less $(P<0.05)$ than those of steers fed the Salt+fat diet.

\section{Carcass}

No treatment differences were found in carcass data in Exp. 1 or 2 (data not shown). Carcass data were not analyzed in Exp. 3. In addition, in Exp. 1 no treatment differences were found in the performance of cattle that remained on their final Latin square diet treatment for the 49-d period between the end of the last period of the Latin square and slaughter (Table 7).

\section{DISCUSSION}

Data from these studies agree with those of the NRC (1996), which state that DMI declines in response to elevated environmental temperatures. High heat load results in a decrease in DMI of 8 to $35 \%$ (Conrad, 1985; Mitlöhner et al., 2001). In Exp. 3, mean DMI reductions (over $5 \mathrm{~d}$ ) of nearly $40 \%$ occurred when climatic conditions shifted from thermoneutral to hot. By the third day of this study, DMI were nearly $70 \%$ less than DMI under thermoneutral conditions. Reductions in DMI of nearly $70 \%$ have been reported in cattle exposed to an extreme heat load (Hahn and Mader, 1997).

Decreases in DMI, of 0.7 to $1.0 \mathrm{~kg} / \mathrm{d}$, as a result of fat supplementation have been reported (Drackley et al., 2003). However, in the current study smaller reductions were observed. Cattle fed the high-fat diet in Exp. 2 had the same DMI as cattle fed the CON2 diet. Adding salt with the fat may have resulted in additional declines in DMI, relative to cattle in the CON2 group.

The mechanisms by which supplemental fat sometimes depresses feed intake are not clear, but could involve the effects of fat on ruminal fermentation and gut motility, the palatability of diets containing added fat, the release of gut hormones, and the oxidation of fat in the liver (Grummer, 1993; Allen, 2000).

Table 7. Average daily gain, DMI, daily water intake (DWI), and G:F of steers (Exp. $1)^{1}$

\begin{tabular}{lcccc}
\hline \hline & \multicolumn{3}{c}{ Treatment } \\
\cline { 2 - 4 } Item & Control & Salt & Salt-soybean & \multirow{2}{*}{ SEM } \\
\hline Initial BW, kg & 459 & 459 & 456 & 5.0 \\
Final BW, kg & 535 & 542 & 534 & 9.0 \\
ADG, kg/d & 1.55 & 1.71 & 1.59 & 0.10 \\
DMI, kg/d & 9.66 & 9.89 & 9.67 & 0.22 \\
DWI, L/d & 27.7 & 27.2 & 25.8 & 1.7 \\
DWI:DMI, L/kg & 2.87 & 2.74 & 2.66 & 0.18 \\
G:F & 0.160 & 0.172 & 0.165 & 0.008 \\
\hline
\end{tabular}

${ }^{1}$ Based on the $49 \mathrm{~d}$ from the end of the Latin square to slaughter. 
Drackley et al. (2003), Palmquist (1994), and Allen (2000) suggested that DMI may be influenced by factors sensitive to the intake of long-chain fatty acids. Unsaturated long-chain fatty acids reaching the intestine decrease DMI (Drackley et al., 2003) because fatrich foods are potent stimulators of cholecystokinin secretion (Palmquist, 1994). Evidence has been presented for a role of increased concentrations of the gut hormones cholecystokinin and glucagon-like peptide- 1 in response to long-chain fatty acids reaching the intestine as mediators of decreased DMI (Drackley et al., 2003). Palmquist (1994) also reported that high-fat diets resulted in an increase in hepatic fatty acid oxidation, which inhibits feed intake.

In Exp. 1 and 3, decreases in DMI may have been an attempt by the steers to maintain body temperature by reducing the metabolic heat load. However, efficiency of energy utilization is reduced in a hotter environment because thermally stressed animals have greater maintenance requirements resulting from elevated body metabolism and activity to alleviate the excess heat load (Beede and Collier, 1986). Therefore, increased dietary energy is used for maintenance requirements as increased work via greater respiration rates to dissipate the excess heat, which in turn increases the rectal temperature and TT.

In contrast, Knapp and Grummer (1991) found that tallow or blended animal and vegetable fat fed at $5 \%$ or more of the diet did not depress DMI. Rather, the type of supplemental fat fed and the way in which fat was presented to cattle may influence acceptability (Knapp and Grummer, 1991). Although cattle may not show signs of reduced heat stress in response to added dietary fat, benefits may be accrued by the greater energy density of the diet during periods of depressed intake.

The least DMI during cold and hot conditions was by cattle consuming diets with added salt, indicating that supplementing salt has a negative effect on DMI. This conflicts with evidence from La Manna et al. (1999) and Schneider et al. (1986), who reported that average DMI was altered $(P=0.17)$ by dietary salt concentration. Dry matter intake tended to increase $(8.94,10.25$, and $10.42 \mathrm{~kg} / \mathrm{d}$ ) as the amount of dietary salt was increased (0, 0.25, and 0.50\%; La Manna et al., 1999), whereas DMI was $5.6 \%$ greater with $0.55 \%$ sodium diets than with 0.18 or $0.88 \%$ sodium diets (Schneider et al., 1986).

The decline in DMI may be explained by the negative effects associated with the chlorine component of salt. Salt contains elevated concentrations $(60.6 \%)$ of chlorine (Granzin and Gaughan, 2002); hence, when salt is supplemented at $1 \%$, the concentration of chlorine in the diet well exceeds $0.15 \%$ of DM, the threshold thought to limit intake (Sanchez et al., 1994). Sanchez et al. (1994) reported a negative linear effect of increasing dietary chlorine on DMI and found that increased dietary chlorine was much more detrimental to DMI during summer than during winter. The negative effect was also evident for chlorine across concentrations of sodium during summer (Sanchez et al., 1994). Furthermore, West (1999) reported that a high-chlorine diet depressed DMI and was associated with reduced blood $\mathrm{pH}$, overwhelmed the capacity of the kidneys to excrete hydrogen ions and to maintain normal blood pH (Sanchez et al., 1994), and reduced blood buffering. Potassium and sodium are the primary cations involved in the maintenance of the blood acid-base chemistry, essentially maintaining blood $\mathrm{pH}$. When cattle are heat stressed, mineral losses occur via drooling, sweating (potassium carbonate and potassium bicarbonate) and urine (bicarbonate ion, sodium, and potassium). Excessive panting increases plasma $\mathrm{pH}$ and bicarbonate, reduces blood buffering capacity, and increases urinary excretion of sodium and bicarbonate ion (Sparke et al., 2001). The dietary cation-anion difference (DCAD) may be more important than the content of the individual elements (Escobosa et al., 1984). Reduced DCAD may induce mild metabolic acidosis (Vagnoni and Oetzel, 1998), and this may act as a trigger for more severe acidosis when feedlot cattle are exposed to an increased heat load. The DCAD in all the experimental diets used in the current studies were greater (35 to $68 \mathrm{mEq}$ ) than the minimum $(25 \mathrm{mEq})$ suggested for dairy cows (Wildman et al., 2007). A value in the range of 15 to $30 \mathrm{mEq}$ has been suggested for growing beef cattle (Ross et al., 1994a,b). Although considerable work has been undertaken to investigate the effects of DCAD on the performance of dairy cows, only limited data are available for beef cattle. Only small amounts of potassium are stored in the body (NRC, 1996); therefore, supplementation during periods of heat stress may be required. Sodium carbonates or sodium bicarbonates may be beneficial in replacing the sodium lost via urine when cattle (dairy cows) are heat stressed (Staples, 2007). Similarly, potassium carbonate and potassium bicarbonate may be used to replace the potassium lost via sweating. It is thought that carbonates and bicarbonates are better than potassium chloride because increased intake of chlorine has been shown to depress DMI in dairy cows in summer (Sanchez et al., 1994).

The mean rectal temperature and TT were within the expected ranges for the nutritional regimens used and for the climatic conditions experienced (Gaughan et al., 1996; Mader et al., 2002; Holt et al., 2004). The mean respiration rate of $55.9 \pm 1.92$ breaths $/ \mathrm{min}$ in thermoneutral conditions within and across all treatments in Exp. 3 was slightly below the baseline respiration rate of 60 breaths/min at the threshold temperature of $21.3^{\circ} \mathrm{C}$ reported by Hahn (1999). The increase in respiration rate when cattle were exposed to hot conditions in Exp. 3 is in agreement with previous studies (Gaughan et al., 1996, 2004).

Across the 3 experiments, cattle fed the high-fat diets had the greatest body temperatures when exposed to cold (Exp. 2) or hot conditions (Exp. 1 and 3). In Exp. 3 , the steers with the greatest rectal temperatures also had the greatest respiration rates. These results are difficult to explain because fat has a low heat increment 
(West, 1999; Drackley et al., 2003) and should therefore contribute little to the metabolic heat load, particularly when DMI is decreased. These results conflict with the results of Soliman et al. (2001), who reported that fat supplementation had no significant effect on rectal temperatures or respiration rates. However, Drackley et al. (2003) reported that cattle fed diets containing high fat and high roughage had reduced rectal temperatures and respiration rates compared with cattle fed a high-concentrate diet. Both Soliman et al. (2001) and Drackley et al. (2003) suggested that the decrease in respiration rates for cattle fed the fat treatments was due to the decreased heat increment associated with metabolism of fat and also was a result of the decreased DMI when cattle were fed the high-fat diets. Nevertheless, in the studies reported herein, the combination of salt and fat addition to diets was not found to be beneficial in reducing body temperature and, in fact, had an opposite effect.

Even though added salt plus fat reduced DMI under hot conditions, these data suggest that switching to diets containing the combination of added salt and fat may elevate body temperature, which would be a deterrent in summer but a benefit to the animal in winter. Under thermoneutral conditions, DMI was increased when salt and when salt plus fat were added to diets. Adding salt by itself resulted in decreased body temperature under hot conditions only. Nevertheless, adding salt or salt plus fat to diets resulted in increased DWI under hot conditions.

These results indicate that treatment differences in DMI may have been due to switching and then adapting to the new treatment diet. Diet ingredients or the combination of ingredients that can be used to control or regulate DMI may limit large increases in DMI and possibly minimize variation in DMI during adverse weather events.

Further studies are required to define the effects of fat and mineral supplementation clearly to detect possible interactions and monitor the response of cattle when fed these supplements while they are exposed to thermal stress. This will allow the development of a response gradient for varying amounts of added fat and salt being fed during times of thermal stress to ascertain which amounts are the most beneficial for production without being detrimental to the health of the animal. Different fat and salt sources should also be considered to identify the sources that are most advantageous regarding performance variables, cost, and availability.

\section{LITERATURE CITED}

Allen, M. S. 2000. Effects of diet on short-term regulation of feed intake by lactating dairy cattle. J. Dairy Sci. 83:1598-1624.

Baldwin, R. L., N. E. Smith, J. Taylor, and M. Sharp. 1980. Manipulating metabolic parameters to improve growth rate and milk secretion. J. Anim. Sci. 51:1416-1428.

Beede, D. K., and R. J. Collier. 1986. Potential nutritional strategies for intensively managed cattle during thermal stress. J. Anim. Sci. 62:543-554.
Conrad, J. H. 1985. Feeding of farm animals in hot and cold environments. Pages 205-226 in Stress Physiology in Livestock. Vol. 1. M. K. Yousef, ed. CRC Press, Boca Raton, FL.

De Dios, O. O., and G. L. Hahn. 1993. Thermoregulation of growing bovines during fall transitional environments. Pages 289-297 in Proc. 4th Int. Livest. Environ. Symp., Coventry, UK. E. Collins and C. Boon, ed. Am. Soc. Agric. Eng., St. Joseph, MI.

Drackley, J. K., T. M. Cicela, and D. W. LaCount. 2003. Responses of primiparous and multiparous Holstein cows to additional energy from fat or concentrate during summer. J. Dairy Sci. 86:1306-1314.

Escobosa, A., C. E. Coppock, L. D. Rowe Jr., W. L. Jenkins, and C. E. Gates. 1984. Effects of dietary sodium bicarbonate and calcium chloride on physiological responses of lactating dairy cows in hot weather. J. Dairy Sci. 67:574-584.

Gaughan, J. B., M. S. Davis, and T. L. Mader. 2004. Wetting and the physiological responses of grain-fed cattle in a heated environment. Aust. J. Agric. Res. 55:253-260.

Gaughan, J. B., T. L. Mader, S. M. Holt, G. L. Hahn, and B. A. Young. 2002. Review of current assessment of cattle and microclimate during periods of high heat load. Anim. Prod. Aust. 24:77-80.

Gaughan, J. B., T. L. Mader, S. M. Holt, M. J. Josey, and K. J. Rowan. 1999. Heat tolerance of Boran and Tuli crossbred steers. J. Anim. Sci. 77:2398-2405.

Gaughan, J. B., T. L. Mader, D. Savage, and B. A. Young. 1996. Effect of feeding regime on feed intake of cattle exposed to heat. Aust. Soc. Anim. Prod. 21:223-226.

Granzin, B. C., and J. B. Gaughan. 2002. The effect of sodium chloride supplementation on the milk production of grazing Holstein Friesian cows during summer and autumn in a humid subtropical environment. Anim. Feed Sci. Technol. 96:147-160.

Grummer, R. R. 1993. Etiology of lipid-related metabolic disorders in periparturient dairy cows. J. Dairy Sci. 76:3882-3896.

Hahn, G. L. 1999. Dynamic responses of cattle to thermal heat loads. J. Anim. Sci. 77(Suppl. 2):10-20.

Hahn, G. L., and T. L. Mader. 1997. Heat waves in relation to thermoregulation, feeding behavior and mortality of feedlot cattle. Pages 563-571 in Proc. 5th Int. Livest. Environ. Symp. Am. Soc. Agric. Eng., St. Joseph, MI.

Holt, S. M., J. B. Gaughan, and T. L. Mader. 2004. Feeding strategies for grain-fed cattle in a hot environment. Aust. J. Agric. Res. 55:719-725.

Huber, J. T., G. Higgenbotham, R. A. Gomez-Alarcon, R. B. Taylor, K. H. Chen, S. C. Chan, and Z. Wu. 1994. Heat stress interactions with protein, supplemental fat, and fungal cultures. J. Dairy Sci. 77:2080-2090.

Knapp, D. M., and R. R. Grummer. 1991. Response of lactating dairy cows to fat supplementation during heat stress. J. Dairy Sci. 74:2573-2579.

La Manna, A. F., F. N. Owens, S. Janloo, T. Shenkoru, and S. D. Welty. 1999. Impact of dietary salt concentrations on water intake and physiological measurements of feedlot cattle. Okla. Agric. Exp. Sta. Res. Rep. P-973:159-164.

Mader, T. L. 2003. Environmental stress in confined beef cattle. J. Anim. Sci. 81 (E Suppl. 2):110-119.

Mader, T. L., J. M. Dahlquist, G. L. Hahn, and J. B. Gaughan. 1999a. Shade and wind barrier effects on summertime feedlot cattle performance. J. Anim. Sci. 77:2065-2072.

Mader, T. L., J. B. Gaughan, and B. A. Young. 1999b. Feedlot diet roughage level for Hereford cattle exposed to excessive heat load. Prof. Anim. Sci. 15:53-62.

Mader, T. L., S. M. Holt, G. L. Hahn, M. S. Davis, and D. E. Spiers. 2002. Feeding strategies for managing heat load in feedlot cattle. J. Anim. Sci. 80:2373-2382.

Mitlöhner, F. M., J. L. Morrow, J. W. Dailey, S. C. Wilson, M. L. Galyean, M. F. Miller, and J. J. McGlone. 2001. Shade and water misting effects on behavior, physiology, performance, and carcass traits of heat stressed feedlot cattle. J. Anim. Sci. 79:2327-2335. 
Montgomery, S. P., J. S. Drouillard, T. G. Nagaraja, E. C. Titgemeyer, and J. J. Sindt. 2008. Effects of supplemental fat source on nutrient digestion and ruminal fermentation in steers. J. Anim. Sci. 86:640-650.

NRC. 1996. Nutrient Requirements of Beef Cattle. 7th rev. ed. Natl. Acad. Press, Washington, DC.

Palmquist, D. L. 1994. The role of dietary fats in efficiency of ruminants. J. Nutr. 124:1377S-1382S.

Raymond, W. H. 2000. Moisture advection using relative humidity. J. Appl. Meteorol. 39:2397-2408.

Ross, J. G., J. W. Spears, and J. D. Garlich. 1994a. Dietary electrolyte balance effects on performance and metabolic characteristics in finishing steers. J. Anim. Sci. 72:1600-1607.

Ross, J. G., J. W. Spears, and J. D. Garlich. 1994b. Dietary electrolyte balance effects on performance and metabolic characteristics in growing steers. J. Anim. Sci. 72:1842-1848.

Sanchez, W. K., M. A. McGuire, and D. K. Beede. 1994. Macromineral nutrition by heat stress interactions in dairy cattle: Review and original research. J. Dairy Sci. 77:2051-2079.

Schneider, P. L., K. K. Beede, and C. J. Wilcox. 1986. Responses of lactating cows to dietary sodium source and potassium quantity during heat stress. J. Dairy Sci. 69:99-110.

Soliman, M., S. Abdelhady, I. Fattouh, K. Ishioka, H. Kitamura, K. Kimura, and M. Saito. 2001. No alteration in serum leptin during acute endotoxemia in sheep. J. Vet. Med. Sci. 63:11431145 .
Sparke, E. J., B. A. Young, J. B. Gaughan, S. M. Holt, and P. J. Goodwin. 2001. Heat Load in Feedlot Cattle. MLA Project FLOT.307, 308, 309. Meat Livest. Australia, North Sydney, New South Wales, Australia.

Staples, C. R. 2007. Nutrient and feeding strategies to enable cows to cope with heat stress conditions. Pages $93-108$ in 22nd Annu. Southwest Nutr. Manage. Conf., Tempe, AZ. Univ. Arizona, Tempe.

Thom, E. C. 1959. The discomfort index. Weatherwise 12:57-59.

Vagnoni, D. B., and G. R. Oetzel. 1998. Effects of dietary cationanion difference on the acid base status of dairy cows. J. Dairy Sci. 81:1643-1652.

West, J. W. 1997. Balancing diets for dairy cattle during heat stress conditions. www.southeastdairyextension.org/heatstress.asp Accessed Jan. 22, 2007.

West, J. W. 1999. Nutritional strategies for managing the heatstressed dairy cow. J. Anim. Sci. 77:21-35.

White, T. W., L. D. Bunting, L. S. Sticker, F. G. Hembry, and A. M. Saxton. 1992. Influence of fish meal and supplemental fate on performance of finishing steers exposed to moderate or high ambient temperatures. J. Anim. Sci. 70:3286-3292.

Wildman, C. D., J. W. West, and J. K. Bernard. 2007. Effect of dietary cation-anion difference and dietary crude protein on performance of lactating dairy cows during hot weather. J. Dairy Sci. 90:1842-1850. 